\title{
Role of Financial Intelligence Unit in Combating Money- Laundering and Terrorist Financing: An Analysis on the Functioning of Bangladesh Financial Intelligence Unit
}

\author{
M. Anwarul Aziz Kanak, \\ Lecturer, Dept. of Law \& Justice, Southeast University, Bangladesh \& M.Phil Research Fellow, \\ Jahangirnagar University,Bangladesh, Email:adv.aaziz@gmail.com
}

\begin{abstract}
Combating the crimes of money laundering and financing terrorism is essential to the integrity of financial systems. Recent efforts to develop effective strategies for anti-money laundering and combating the financing of terrorism (AML/CFT) bring together several distinct but related aspects of financial systems and criminal law. Financial intelligence units (FIUs) constitute an important component of these strategies. An FIU is a central national agency responsible for receiving, analyzing, and transmitting disclosures on suspicious transactions to the competent authorities. This paper briefly reviews the development of the global network of FIUs and their system of information gathering. This paper also looks back the overall functioning of the Bangladesh Financial Intelligence Unit (BFIU) keeping in line with the set international standards and gives recommendations on the areas to be improved to ensure its better functioning. This work is a theoretical analysis of the existing international instruments regulating the functioning of FIU worldwide and also the Bangladesh laws dealing with the working of Bangladesh Financial Intelligence Unit- BFIU.
\end{abstract}

Key words: Financial Intelligence unit, Bangladesh Financial Intelligence Unit, Anti-money laundering,Combating the Financing of Terrorism

\section{INTRODUCTION}

The need for a modern anti-money-laundering strategy has become widely accepted internationally. As countries developed their anti-money-laundering strategies and found that law-enforcement agencies had limited access to relevant financial information, it became clear that the strategy required them to "engage the financial system in the effort to combat laundering while, at the same time, seeking to ensure the retention of the conditions necessary for its efficient operation. ${ }^{1}$ Countries also found that implementation of a system requiring disclosures of suspicious transactions on the part of financial institutions created the need for a central office or agency for assessing and processing these disclosures. ${ }^{2}$ In this connection, countries have started to establish central intelligence units to this effect known as Financial Intelligence Unit-FIU. The first few financial intelligence units (FIUs) were established in the early 1990s in response to the need for a central agency to receive, analyze, and disseminate financial information to combat money laundering. ${ }^{3}$ Over the following ten years, the number of FIUs increased to the point where the Egmont Group ${ }^{4}$, the informal international association of FIUs, had 94 members and the membership now rose to 151 members till date. In 2003, the

\footnotetext{
${ }^{1}$ William C. Gilmore, 1999, Dirty Money: The Evolution Of Money-Laundering Counter- Measures, 2nd ed. (Strasbourg: Council of Europe Press), page 103.

${ }^{2}$ Egmont Group, 1995, The First International Meeting of Organizations Devoted to Anti- Money Laundering (Brussels), page 1 .

${ }^{3}$ Egmont Group.2004b. “ Interpretive note concerning the Egmont definition of financial intelligence unit, November 15.

${ }^{4}$ A group of Financial Intelligence Units (FIUs) at the Egmont Arenberg Palace in Brussels, Belgium, decided to establish an informal network of FIUs for the stimulation of international co-operation. Now known as the Egmont Group of Financial Intelligence Units.
} 
Financial Action Task Force (FATF) ${ }^{5}$ adopted a revised set of recommendations on combating money laundering that, for the first time, included explicit recommendations on the establishment and functioning of FIUs. 3 In recent years, recognizing the importance of an FIU in the anti-money laundering/combating the financing of terrorism (AML/CFT) framework, the International Monetary Fund and the World Bank, as well as a number of their member countries, have provided technical assistance to countries in the establishment and strengthening of FIUs. Although the FIU members of the Egmont Group share the same core functions of receiving, analyzing, and disseminating financial information to combat money laundering and financing of terrorism, ${ }^{6}$ they differ in many ways. Authorities intending to establish an FIU or improve an existing FIU's effectiveness face a number of choices concerning how the FIU is to be established and function. Similarly, providers of technical assistance regarding FIUs need access to a wide array of information as to the various aspects of FIUs. Thus, it is required to provide FIU officials, country authorities, and providers of technical assistance with an overview of the range of experience countries and FIUs have had up to now.

Moreover, FIUs currently face a series of unique challenges. The scope of their responsibilities is being widened to include dealing with the financing of terrorism, in addition to money laundering and the related predicate offenses. Financial information related to the financing of terrorism is, in many ways, different from financial information regarding other crimes, thus raising issues of methods of information analysis and of training for FIU staff. In response to the International call, Bangladesh also has set up a financial intelligence unit under Bangladesh Bank- Central Bank of Bangladesh, named as Bangladesh Financial Intelligence Unit BFIU to fight out all sorts of financial crimes and to stop the flow of money being instilled in terrorist activities. $^{7}$

This paper briefly reviews the development of the global network of FIUs and their system of information gathering. This paper also reviews the overall functioning of the Bangladesh Financial Intelligence Unit (BFIU) keeping in line with the set international standards and gives recommendations on the areas to be improved to ensure its better functioning. This paper is a theoretical analysis of the existing international instruments regulating the functioning of FIU worldwide and also the Bangladesh laws dealing with the working of Bangladesh Financial Intelligence Unit- BFIU.

\section{FINACIAL INTELLIGENCE UNIT (FIUs)}

Every country should establish a financial intelligence unit (FIU) that serves as a national centre for the receipt and analysis of: (a) suspicious transaction reports; and (b) other information relevant to money laundering, associated predicate offences and financing of terrorism, and for the dissemination of the results of that analysis. The FIU should be able to obtain additional information from reporting entities, and should have access on a timely basis to the financial, administrative and law enforcement information that it requires to undertake its functions properly. A few major considerations shape the creation of the FIUs: anti-money laundering and counter terrorism financing laws, existing law enforcement, and the need for an authority that will receive, assess and share financial information.

The FATF Interpretive Note to Recommendation $29^{8}$ determines that countries should ensure that the FIU has regard to the Egmont Group statement of purpose and its Principles for Information Exchange Between Financial Intelligence Units for Money Laundering and Financing of Terrorism Cases (these documents set out important guidance concerning the role and functions of FIUs, and the mechanisms for exchanging information between FIUs. The FIU should apply for membership in the Egmont Group.

There are four models of FIUs: judicial, law enforcement, Administrative, and hybrid. ${ }^{9}$

\footnotetext{
${ }^{5}$ The Financial Action Task Force (FATF) is an inter-governmental body established in 1989 by the the G-7Summit in Paris as a result of the professed need to internationalize the fight against drug trafficking - then perceived as a key source of laundered money.. The mandate of the FATF is to set standards and to promote effective implementation of legal, regulatory and operational measures for combating money laundering, terrorist financing and the financing of proliferation, and other related threats to the integrity of the international financial system.

${ }^{6}$ Egmont Group, June 2004, Statement of Purpose of the Egmont Group of Financial Intelligence Units (Guernsey).

${ }^{7}$ https://bangladesh-bank.org/bfiu/index.php (accessed date 24.0620016).

${ }^{8}$ FATF interpretive note on Recommendation 29 : Competent authorities, their powers and resources.

9 D'Souza, Jayesh. Terrorist financing, money laundering, and tax evasion: Examining the performance of financial intelligence units. CRC Press, 2011.
} 
- The Judicial Model is established within the judicial branch of government wherein "disclosures" of suspicious financial activity are received by the investigative agencies of a country from its financial sector such that the judiciary powers can be brought into play e.g. seizing funds, freezing accounts, conducting interrogations, detaining people, conducting searches, etc.

- $\quad$ The Law Enforcement Model implements anti-money laundering measures alongside already existing law enforcement systems, supporting the efforts of multiple law enforcement or judicial authorities with concurrent or sometimes competing jurisdictional authority to investigate money laundering.

- The Administrative Model is a centralized, independent, administrative authority, which receives and processes information from the financial sector and transmits disclosures to judicial or law enforcement authorities for prosecution. It functions as a "buffer" between the financial and the law enforcement communities.

- $\quad$ The Hybrid Model serves as a disclosure intermediary and a link to both judicial and law enforcement authorities. It combines elements of at least two of the FIU models.

\section{INTERNATIONAL INITIATIVES}

Although the international community quickly developed standards on combating money laundering in general, mostly through the work started by the FATF in 1989, formal recognition of the FIU as a crucial element in anti-money laundering strategy is more recent. In the 1990 FATF Recommendations, mention was made of the need for financial institutions to report suspicious transactions to "the competent authorities," but these "competent authorities" were not defined, and could be any government agency designated for the purpose. It is only with the issuance of the 2003 Recommendations that the FATF Recommendations recognized the need for an FIU in the sense defined by the Egmont Group.

\subsection{The FATF Recommendations relating to FIUs}

The 1990 FATF Recommendations mentioned "competent authorities" for receiving and processing suspicious transaction reports. ${ }^{10}$ The recommendations touched upon the main roles of "competent authorities" and alluded to some of the functions and attributes that could be vested in such authorities (without requiring that FIUs have all of them): receiving suspicious or currency transactions above a certain limit; giving instructions to financial institutions; having a computerized database, compliance control and supervision powers, and regulatory powers; issuing guidelines; and carrying out international information exchange. Some of the rules governing suspicious transaction reports were also set out in the recommendations, such as the immunity enjoyed by those who make reports to the FIU in good faith and the rule against "tipping off." about this same time, the first national FIUs were being established. The 1996 FATF Recommendations did not introduce major changes in the manner in which the recommendations referred to "central authorities" in the context of reporting suspicious transactions". 12 The FATF Special Recommendations on Terrorist Financing, adopted in October 2001, broadened the scope of the reporting obligation to include transactions suspected of being related to terrorist financing. ${ }^{13}$ The issuance of the revised 40 FATF Recommendations in June 2003 marks an important milestone in the evolution of the FATF's approach to FIUs. Largely on the basis of the work of the Egmont Group, the recommendations, for the first time, explicitly mention the FIU as the recipient of reports of suspicious transactions and specify that countries should establish FIUs. ${ }^{14}$ With the FIU firmly established as one of the "competent authorities" in the AML/CFT system, Recommendation 30, which specifies that competent authorities should have adequate financial, human, and technical resources, clearly applies to FIUs. Similarly, Recommendation 40, which specifies that countries should ensure that their competent authorities provide "the widest possible range of international cooperation to their foreign counterparts" and that "exchanges should be permitted without unduly restrictive conditions," also applies to FIUs.

\footnotetext{
${ }^{10}$ Recommendations 16, 18, 24, 26, 27, 28, and 32 mention "competent authorities" in this context..

11 Recommendations 16 and 17 (1990).

${ }^{12}$ Recommendations 15, 18, 23, 26, 27, 29, and 32 dealt with "competent authorities."

${ }^{13}$ FATF Special Recommendation on Terrorist Financing IV.

${ }^{14}$ FATF Recommendations 13 and 26 (2003); the methodology developed by the IMF, the World Bank, and the FATF in 2001 mentioned FIUs specifically. 


\subsection{International Conventions}

In the last few years, a number of international conventions have recognized the usefulness of FIUs in modern anti-money-laundering systems and have encouraged the states that are parties to these conventions to establish FIUs. These are (in the order in which they were opened for signature), the Convention for the Suppression of the Financing of Terrorism (1999), the United Nations Convention Against Transnational Organized Crime (2001), and the United Nations Convention Against Corruption (2003).

The first of these conventions requires the criminalization of the financing of terrorism; the second requires the criminalization of participation in organized international criminal groups, corruption, money laundering, and obstruction of justice. The third requires the criminalization of various forms of corruption, money laundering, concealment of the proceeds of crime, and obstruction of justice. One common element in the three conventions is that each one requires states that are parties to criminalize money laundering and to adopt measures to prevent it. The preventive measures are, in large part, inspired by the FATF recommendations and include references to the reporting of suspicious transactions to competent authorities. ${ }^{15}$ In the two most recent conventions, the references to the FIU are explicit. For example, the United Nations Convention Against Transnational Organized Crime requires states that are parties to "ensure that administrative, regulatory, law-enforcement and other authorities dedicated to combating money-laundering ... have the ability to cooperate and exchange information at the national and international levels... and to that end, shall consider the establishment of a financial intelligence unit to serve as a national centre for the collection, analysis and dissemination of information regarding potential money-laundering." 16

\subsubsection{Norms and Standards on FIUs in European Union}

The Council Directive on prevention of the use of the financial system for the purpose of money laundering of 1991 embodied the basic requirements of sound anti-money-laundering programs, including customer identification, record keeping, and the blocking of suspicious transactions. With respect to FIUs (which were not mentioned as such but were included among the "authorities responsible for combating money laundering"), the directive contained three basic principles: (i) full cooperation of financial institutions with these authorities by furnishing to them, on their own initiative, information on any fact that might be an indication of money laundering and furnishing to them additional information on their request; (ii) blocking suspicious transactions until the responsible authorities had been notified; and (iii) furnishing information to the FIU whenever, as a result of an inspection or otherwise, supervisors or regulators of financial institutions discover facts that could constitute evidence of money laundering. ${ }^{17}$

EU action plan to combat organized crime was endorsed at the Amsterdam European Council in June 1997, stated that "money laundering is at the very heart of organized crime." Although the action plan was directed mainly at cooperation among law-enforcement agencies, it also included preventive measures; and, in particular, it recommended the establishment of a system for exchanging information concerning suspected money laundering at the European level which was followed by Council Decision of October 17, 2000. ${ }^{18}$

The 1999 European Council meeting in Tampere, Finland was devoted to "the creation of an area of freedom, security and justice in the European Union." One of its pillars is an EU-wide fight against organized and transnational crime in which special actions against money laundering are called for. One of these actions attempts to remove the remaining legal obstacles to the exchange of information among member states' FIUs. The Presidency Conclusions state that "regardless of secrecy provisions applicable to banking and other

\footnotetext{
${ }^{15}$ Convention for the Suppression of the Financing of Terrorism, Article 18 (b) (ii); United Nations Convention Against Transnational Organized Crime, Article 7, paragraph 1 (a); and United Nations Convention Against Corruption, Article 14, paragraph 1 (a).

${ }^{16}$ United Nations Convention Against Transnational Organized Crime, Article 7, paragraph 1 (b). The United Nations Convention Against Corruption contains similar language (Article 58).

${ }^{17}$ Council Directive 91/308/EEC of 10 June 1991 on prevention of the use of the financial system for the purpose of money laundering [Official Journal L 166 of 28.06.1991.

${ }^{18}$ UNSPECIFIED (1997) Amsterdam European Council 16-17 June 1997. Presidency conclusions and annexes. [EU European Council]. 
commercial activity, judicial authorities as well as FIUs must be entitled, subject to judicial control, to receive information when such information is necessary to investigate money laundering." ${ }^{, 19}$

EC Council Decision of October 17, 2000 concerning arrangements for cooperation between financial intelligence units of the Member States in respect of exchanging information Council Decision of October 17, 2000, which followed the Action Plan to Combat Organized Crime mentioned above, sets out detailed requirements to improve the exchange of information between FIUs. The decision endorses the Egmont Group definition of an FIU and requires that performance of their functions (including the exchange of information) not be affected by their internal status, "regardless of whether they are administrative, law-enforcement or judicial authorities. ${ }^{20}$ Directive 2001/97/EC of the European Parliament and the Council of December 4, 2001 amending the Council Directive 91/308/EEC on prevention of the use of the financial system for the purpose of money laundering The 2001 amendments to the 1991 Directive reiterate the basic obligation of full cooperation and reporting of suspicious transactions set out in the 1991 Directive and extends its scope beyond financial institutions to a number of activities and professions susceptible to money laundering. ${ }^{21}$

\section{ESTABLISHMENT OF BANGLADESH FINANCIAL INTELLIGENCE UNIT (BFIU)}

As discussed earlier, the nature of BFIU is administrative type which is the part of the Central Bank serving as a link between reporting agencies and law enforcement agencies. ${ }^{22}$ This is the central agency of Bangladesh responsible for analyzing Suspicious Transaction Reports (STRs), Cash Transaction Reports (CTRs) \& information related to money laundering (ML) /financing of terrorism (TF) received from reporting agencies \& other sources and disseminating information/intelligence thereon to relevant law enforcement agencies. ${ }^{23}$ BFIU has been entrusted with the responsibility of exchanging information related to money laundering and terrorist financing with its foreign counterparts. The main objective of the BFIU is to establish an effective system for prevention of money laundering, combating financing of terrorism and proliferation of weapons of mass destruction. BFIU was established in June 2002, in Bangladesh Bank (Central bank of Bangladesh) named as Anti Money Laundering Department (AMLD). To enforce and ensure the operational independence of FIU, AMLD has been transformed as the Bangladesh Financial Intelligence Unit (BFIU) in 25 January, 2012 under the provision of Money Laundering Prevention Act, 2012 and has been bestowed with operational independence. BFIU has also achieved the membership of Egmont Group in July, 2013 BFIU works under the provisions of Money Laundering Prevention Act, 2012 and Anti-Terrorism Act, 2009 (including amendments in 2013). ${ }^{24}$ The government is planning to give full autonomy to the central bank's financial intelligence unit so it can deal with financial crimes independently. To that end, the finance ministry has already sent a proposal to the Cabinet Division. According to the proposed change in the law, the government will appoint the chief executive and deputy chief executive of Bangladesh Financial Intelligence Unit (BFIU) on a full-time basis. Officials of Bangladesh Bank will work for the unit on deputation. ${ }^{25}$ In an effort to facilitate the sharing of information between FIUs, Bangladesh has included provisions under section 26 the MLPA whereby the Government or, in some cases, Bangladesh Bank can sign a MOU, enter into bilateral or multilateral contracts, conventions or sign contracts with any foreign country or organization by means of acceptance of international legislation. Under this section, after signing a contract with a foreign country or agency to prevent ML, the Bangladesh Bank shall request that foreign country or organization to provide relevant information; and

\footnotetext{
19 Tampere European Council 15 and 16 October, 1999 Presidency Conclusions. Finland.

${ }^{20}$ Council Decision of 17 October 2000 concerning arrangements for cooperation between financial intelligence units of the Member States in respect of exchanging information [ Official Journal L 271, 24/10/2000 P. 0004 - 0006].

${ }^{21}$ Directive 2001/97/EC of the European Parliament and of the Council of 4 December 2001 amending Council Directive 91/308/EEC on prevention of the use of the financial system for the purpose of money laundering.

${ }^{22}$ D'Souza, Jayesh. Terrorist financing, money laundering, and tax evasion: Examining the performance of financial intelligence units. CRC Press, 2011.

${ }^{23}$ See section 8 of the S.R.O No. 357-Law/2013 ( In exercise of the power conferred to the Government under section 29 of the Act No. v of 2012).

${ }^{24}$ https://www.bb.org.bd/bfiu/ (accessed date 24.06.2016).

${ }^{25} \mathrm{http}: / /$ www.thedailystar.net/backpage/bb-intel-unit-get-autonomy-128122 (accessed date 24.06.2016). 
to provide information to that foreign country or organization if the requested information is not a threat to national security. ${ }^{26}$

\section{FUNTIONS OF BFIU UNDER THE MLPA AND ATA ACT}

The BFIU is designated as the competent authority to receive STRs and CTRs from the reporting agencies as set out under section 23 of the Money Laundering Prevention Act, 2012-MLPA. ${ }^{27}$ The AMLD also received public 'tip offs' regarding ML. Under section 15 of the Anti-Terrorism Act, 2009-ATA, the Bangladesh Bank has the power/authority to call for and receive STRs related to $\mathrm{TF}^{28}$ The FIU is presently performing such functions.

\subsection{Receipt}

At present the BFIU receives all STRs in paper form via messenger, facsimile or email. The STRs are received by the senior management of the FIU, and this role is delegated to an acting officer in the General Manager's absence. All STRs received are entered onto the database by the analysis wing. It may take more than a day before the analysis wing receives the STR for entry onto the database and analysis can commence. CTRs are received on CD-rom via post and entered onto the database as batch files. CTRs are received from reporting institutions on a monthly basis.

\subsubsection{Obtaining additional information from reporting parties}

Section 23 of the MLPA ${ }^{29}$ provides powers to the AMLD to call for and receive from reporting organizations any information related to the transactions where there is reasonable grounds to suspect that the transaction is involved with money laundering. The reporting entities include banks, financial institutions, insurance companies, money changers, companies and organizations remitting or transferring money, other business organizations approved by the Bangladesh Bank, organizations as the Bangladesh Bank with the approval of Government may notify from time to time ${ }^{30}$. The ATA does not provide the FIU, either directly or indirectly with authority to obtain from reporting parties additional information needed to properly undertake its functions to analyze CFT related STRs. FIU staff indicated that they would rely on powers in the MLPA to request data from reporting institutions in the case of suspected TF. In the absence of TF being included as a predicate offence in the MLPA, there are some gaps in relying on the MLPA to gain data to analyze CFT related STRs.

\subsection{Analysis}

The analysis wing of the BFIU has nine staff divided into three or four teams undertaking the analysis function. Analysts utilize i2 software and Analyst Notebook to assist their analysis.FIU analysts work closely with the police in their work to analyze STRs and CTRs to develop financial intelligence ahead of a possible dissemination. The FIU works closely with the Central Intelligence Cell of the Police CID to check police data holdings. The quality and timeliness of the analysis is limited somewhat by the lack of direct access to administrative and law enforcement information. Relevant records must be requested via letters from the FIU. Most records of other agencies are kept in manual form, which adds to delays in retrieving data in response to BFIU request letters. The analysis function of the AMLD is assisted by bi-monthly feedback sessions between the FIU analysis wing and the Police CID, who share law enforcement insights. BFIU analysts undertake strategic analysis by visiting the CID to identify crime trends. The BFIU database includes STRs received over a number of years, as well as CTR data. The FIU is affected by regular daily blackouts during office hours (up to two hours per day) during which analysts are unable to access the FIU database and other analytical tools, including desktop computers. This is a serious impediment to effective analysis. Typically the analysis wing takes between two weeks and 3 months to complete analysis of a complex STR.CTRs are not subject to electronic matching at time of their entry onto the database to correlate new records with existing CTRs or previous analysis results.

\subsubsection{Access to financial, administrative and law enforcement information to support analysis}

\footnotetext{
${ }^{26}$ See the Act No. V of 2012.

${ }^{27}$ Ibid.

${ }^{28}$ See Act No. XVI of 2009.

29 See the Act No. V of 2012.

${ }^{30}$ Ibid. 
The BFIU does not have direct access to any financial, administrative, or law enforcement databases such as National Board of Revenue, Bangladesh Police, or Customs. Most records of other agencies are kept in manual form, which adds to delays in retrieving data following a request by the FIU.

The BFIU can and has requested further information from the police and other enforcement agencies. The turnaround time for receiving information varies and is on a case by case basis. On average it can take between fifteen to thirty days to receive a response. This is results in very significant delays in the analysis process. There are no clear channels to conduct urgent requests for information from law enforcement agencies.

\subsection{Dissemination}

The function of the BFIU to disseminate information to the investigation agency is indirectly defined in the MLPA, with section 23 (1) (g) and 23 (2) $)^{31}$ providing for the Bangladesh Bank to carry out any related function to meet the objectives of the MLPA; and the Bangladesh Bank shall provide information to the investigating agency if the investigation agency requests information relating to ML or suspicious transactions. The central investigation agency is the Anti-Corruption Commission (ACC) established under the AntiCorruption Act, $2004^{32}$.However, ACC can delegate its investigating power to any other law enforcing agencies like CID -Central Investigation Department under Police and to some extent National Board of Revenue NBR as it deems fit $^{33}$ The ATA under Section $15^{34}$ authorizes dissemination of STRs and other information to the police for investigations of terrorism offences. The FIU does not produce regular summary reports to share typologies and trend information with other law enforcement agencies. The FIU still maintains a working relationship with CID to support the FIU's conduct of preliminary investigation in respect of possible ML cases. CID considers financial intelligence shared by the FIU and forwards on results of preliminary inquiries to the FIU to assist their analysis, which the FIU may consider disseminating to the ACC for investigation. For TF, under section 15(2) of the ATA, the FIU is authorized to disseminate STRs to appropriate law enforcement authorities. The investigation authority in this case has been assigned to Bangladesh Police and the CID would be the investigating wing. ${ }^{35}$

\section{SUFFICIENT OPERATIONAL INDEPENDENCE AND AUTONOMY}

The BFIU is located within the Bangladesh Bank and is a unit within the AMLD. BFIU is responsible for all decisions regarding analysis and dissemination of STRs and other financial intelligence, and there is no indication of interference or undue influence from the Bangladesh Bank in the decision making processes of the BFIU. ${ }^{36}$ The overall policies of the Bangladesh Bank govern the operations of the FIU, but the day to day management of the BFIU is left to the BFIU General Manager. The influence of Bangladesh Bank has been positive to set up and support the operation of the BFIU, including provision of the current budget. ${ }^{37}$ The staffing of the FIU is managed by the Human Resource Department of the Bangladesh Bank. Selection of persons who become part of the BFIU or the AMLD is also undertaken by the Human Resource Department. In practice, the Director of the FIU has been able to retain a dedicated and skilled workforce to man the BFIU. There is a gap, however, with the discretion of the management of the FIU to hire and retain staff. ${ }^{38}$

\section{SECURE AND LAWFUL USE OF INFORMATION HELD BY BFIU}

The BFIU is physically located within a building of the Bangladesh Bank. Entrance to the building is secure and security pass controlled. Access to the AMLD is restricted to AMLD staff, although the AMLD office is not totally enclosed.

\footnotetext{
${ }^{31}$ Ibid.

${ }^{32}$ See the Act No. V of 2004.

${ }^{33}$ See section 6 of the S.R.O No. 357-Law/2013 ( In exercise of the power conferred to the Government under section 29 of the Act No. $v$ of 2012).

${ }^{34}$ See Act No. XVI of 2009.

${ }^{35} \mathrm{Ibid}$.

${ }^{36}$ See section 9 of the S.R.O No. 357-Law/2013 ( In exercise of the power conferred to the Government under section 29 of the Act No. v of 2012).

${ }^{37}$ See .R.O No. 357-Law/2013 ( In exercise of the power conferred to the Government under section 29 of the Act No. v of 2012).

38 Ibid. 
The BFIU is set up as an office within the AMLD. Entrance to the FIU is through a single locked door. The BFIU computer server is in a separate room off the BFIU office with a locking door. There are some gaps with integrity of data and safekeeping of material as the BFIU is not in a separate self-contained location/office. The AMLD and BFIU have locking filing cabinets to secure material to secure hard copy material, but lack combination safes to store sensitive material.

The computer server and database are password protected. The password, which is changed regularly, is held by the General Manger of the AMLD. Access to the database is granted by the General Manager (or a deputized manager in his absence) who logs the 9 analysts into the system each day. Only 9 analysts are granted such access.The BFIU and wider Bangladesh law enforcement lacks a system for security classification of sensitive data and related data handling protocols.

\section{PUBLICLY REPORTS ON BFIU ACTIVITIES AND ML/TF TRENDS}

At present the FIU does not release period reports of its activities, nor of typologies and trends information. The Annual Report of the Bangladesh Bank does not include information on the operation of the BFIU. The BFIU holds meetings twice a year with compliance officers of reporting agencies to provide feedback, including statistics and typologies, but such data is not yet published. The BFIU has done a lot of awareness training and media engagement to raise public awareness about its activities.

MLPA under section $23(1)(\mathrm{g})$ and 23 (2) provides for the Bangladesh Bank to carry out any related function to meet the objectives of the MLPA; and the Bangladesh Bank shall provide information to the investigating agency if the investigation agency requests information relating to ML or suspicious transactions. ${ }^{39}$

BFIU recently sent letters to the banks asking them to do more. Bangladesh Bank also asked managing directors of the banks - Sonali, Janata, Agrani, Rupali and Basic - to submit their work plans for prevention of money laundering and terror finance. BFIU recently rated the five banks on their anti-money laundering and terror finance activities. It found their performance 'unsatisfactory'. ${ }^{40}$

\section{RECENT SUCSESS OF BANGLADESH}

One of the major successes of BFIU is the Bangladesh came out of the FATF 'Grey List" ${ }^{41}$ very recently meaning there would be a great reduction in the costs and time line of transactions with the rest of the world. The FATF welcomes Bangladesh's significant progress in improving its AML/CFT regime and notes that Bangladesh has established the legal and regulatory framework to meet its commitments in its action plan regarding the strategic deficiencies that the FATF had identified in October 2010.Bangladesh is therefore no longer subject to FATF's monitoring process under its on-going global AML/CFT compliance process. Bangladesh will work with $\mathrm{APG}^{42}$ as it continues to address the full range of AML/CFT issues identified in its mutual evaluation report. ${ }^{43}$ Moreover, Bangladesh is set to disclose its three years (2015-2017) strategic paper for curbing illicit financial flows in the country. The strategies were approved in April last at the fourth meeting of National Coordination Committee (NCC) on Anti-Money Laundering (AML) and Counter Terrorist Financing (CFT).The objectives of National Strategy for Preventing Money Laundering and Combating Financial of Terrorism for the year of 2015-17 is to set a comprehensive medium term goal and action agenda in strengthening the capacity of all stakeholders in implementing the provisions of the relevant UN Conventions. ${ }^{44}$

\footnotetext{
${ }^{39}$ See the Act NO. V of 2012.

40 http://bdnews24.com/economy/2015/04/13/bangladesh-bank-asks-5-state-run-banks-to-do-more-to-prevent-moneylaundering-terror-finance.

${ }^{41}$ The FATF blacklist or OECD blacklist issued by the Financial Action Task Force since 2000 and lists countries which it judges to be non-cooperative in the global fight against money laundering and terrorist financing, calling them "NonCooperative Countries or Territories" (NCCTs).

${ }^{42}$ The Asia/Pacific Group on Money Laundering (APG) is an autonomous and collaborative international organization founded in 1997 in Bangkok, Thailand consisting of 41 members and a number of international and regional observers. Some of the key international organizations who participate with, and support, the efforts of the APG in the region include the Financial Action Task Force, International Monetary Fund, World Bank, OECD, United Nations Office on Drugs and Crime, Asian Development Bank and the Egmont Group of Financial Intelligence Units.

43 Bangladesh MER,2009,published by The Asia/Pacific Group on Money Laundering (APG) available at http://www.apgml.org/documents/default.aspx?s=date\&c=7\&pcPage=4 (accessed date 24.06.2016).

${ }^{44} \mathrm{http}$ ://businessnews-bd.com/bangladesh-to-disclose-anti-money-laundering-strategies-for-2015-17/ a (accessed date 24.06.2016).
} 


\section{RECOMMEDATIONS AND COMMENTS: \\ 10.1 General challenges}

In Bangladesh, Two general challenges appear as constants in the improvement of BFIU. Firstly, factors such as the structure and relative importance of financial crime in the country, the government's objectives in combating this form of criminality, the resources available for the task, and the legal and administrative systems of the country all have to be taken into consideration to improve the performance of the country's financial intelligence unit.The second challenge is to keep itself changing with the diverse scenario of the money laundering and terrorist financing phenomenon. In this connection, BFIU has to take more dynamic approaches in order for securing a quite acceptable position among FIUs of other jurisdictions.

\subsection{Specific challenges}

Beside general challenges, there are some specific challenges to be dealt with. The most important ones are the integration of the financing of terrorism in their work, the broadening of the suspicious transaction reporting obligation beyond the regulated financial sector, and the quest for improved international cooperation.

The second specific challenge faced by FIUs is the broadening of the reporting obligation (and other preventive obligations) to entities beyond the prudentially regulated financial institutions.

The third specific challenge is the need to improve the ability of FIUs to engage in international cooperation. The dynamic growth in FIUs worldwide has been accompanied by a strong growth in international cooperation between FIUs

\subsection{Other recommendations:}

I. Overall the Bangladesh FIU has taken significant strides to develop its capacity to receive, analyze and disseminate STRs, CTRs and other data, however due to the prevailing political conditions, there has been a sharp decline in STRs received and impediments top dissemination, which has undermined effectiveness over the past two years

II. In order to improve the receipt of STRs and CTRs from reporting institutions a facility for online reporting should be implemented.

III. The overall quality and depth of analysis should be enhanced through greater understanding of ML and TF risks/typologies in Bangladesh, improved analytical tools, further staff training, and timely access to all available government and open source information.

IV. The BFIU should be provided with direct access to external databases that are accessible electronically such as the police, customs, and other government agencies and/ or as they become automated.

V. There is a need for more regular inter-agency meetings/cooperation/coordination with the ACC, CID, Customs, etc to understand ML and TF risks, techniques and to develop strategies to analyze STRs.

VI. MOUs are required to support domestic and international information sharing. An independent IT assessment should be conducted to determine appropriate database and analytical tools for the FIU perform receipt, analysis and dissemination functions as well as recording statistical data and generating acknowledgement messages when STRs and CTRs are received

VII. Continuous power supply is required to ensure FIU servers and computer equipment is readily available during office hours. Integrity of data and safekeeping of material is requiring in order seeking the cooperation of other foreign governments. A separate self contained location/office for the AMLD and BFIU is needed to ensure security of information for the core FIU functions; secure cabinets such as safes with combination locks are needed for the storing of sensitive material.

VIII. Bangladesh Bank should ensure that the management of the BFIU has autonomy in staff selection and retention within the BFIU.

IX. The system of keeping statistics should be improved to ensure comprehensive data to ensure a better review of the effectiveness of the system.

\section{CONCLUSION}


FIUs ability to transform data into financial intelligence is a key element in the fight against money laundering and the financing of terrorism. The place of FIUs is in now well established in the arsenal of measures to combat these serious crimes In particular, removing legal obstacles that remain in the way of information sharing and developing and improving systems to ensure the confidentiality of exchanged information remain crucial challenges which need to be addressed in no time to see the BFIU is function efficiently keeping pace with the progressive international standards in the field of combating money laundering and terrorist financing. Therefore, International community's need to take policy to combat money laundering, reminding the administrative and financial constrains of the developing countries. Further researches may be conducted to identify the area and resources necessary for the developing countries to combat money laundering.

\section{REFERENCES}

[1] Gilmore, William C. Dirty money: The evolution of money laundering counter-measures. Edited by Conseil de l'Europe. Vol. 609. Strasbourg: Council of Europe, 1999.

[2] Unger, Brigitte, and Daan Van der Linde, eds. Research Handbook on Money Laundering. Edward Elgar Publishing, 2013.

[3] D'Souza, Jayesh. Terrorist financing, money laundering, and tax evasion: Examining the performance of financial intelligence units. CRC Press, 2011.

[4] Kutubi, Shawgat S. "Combating Money-Laundering by the Financial Institutions: An Analysis of Challenges and Efforts In Bangladesh." World Journal of Social Science 1, no. 2 (2011): 36-51.

[5] Gelemerova, Liliya. "On the frontline against money-laundering: the regulatory minefield." Crime, Law and Social Change 52, no. 1 (2009): 33-55.

[6] Unger, Brigitte, and Johan Den Hertog. "Water always finds its way: Identifying new forms of money laundering." Crime, law and social change57, no. 3 (2012): 287-304.

[7] Alexander, Kern. "The international anti-money-laundering regime: The role of the financial action task force." Journal of Money Laundering Control 4, no. 3 (2001): 231-248.

[8] Waris, Attiya, and Laila Abdul Latif. "Black Money Whitening Law: A Study From Bangladesh." (2013).

[9] FATF Recommendations on money laundering and terrorist financing available at

[10] http://www.fatf-gafi.org/publications/fatfrecommendation.

[11] United Nations Convention Against Illicit Traffic in Narcotic Drugs and Psychotropic Substances, opened for signature 20th December, 1988, UNDoc. E/CONF.82/15, 28 ILM 497, available at http://www.unodc.org/unodc/en/treaties/illicit-trafficking.html

[12] United Nations Convention against Transnational Organized Crime available at https://www.unodc.org/unodc/treaties/CTOC/.

[13] Council Directive 91/308/EEC of 10 June 1991 on prevention of the use of the financial system for the purpose of money laundering [Official Journal L 166 of 28.06.1991] available at http://eurlex.europa.eu/legalcontent/EN/TXT/?uri=URISERV\%3A124016.

[14] Directive 2001/97/EC of the European Parliament and of the Council of 4 December 2001 amending Council Directive 91/308/EEC on prevention of the use of the financial system for the purpose of money laundering - Commission Declaration [Official Journal L 344 , 28/12/2001 P. 0076 - 0082] available at http://eur-lex.europa.eu/legalcontent/LV/ALL/?uri=CELEX\%3A32001L0097.

[15] DIRECTIVE (EU) 2015/849 OF THE EUROPEAN PARLIAMENT AND OF THE COUNCIL of 20 May 2015 on the prevention of the use of the financial system for the purposes of money laundering or terrorist financing, amending Regulation (EU) No 648/2012 of the European Parliament and of the Council, and repealing Directive 2005/60/EC of the European Parliament and of the Council and Commission Directive 2006/70/EC available at http://eur-lex.europa.eu/legalcontent/EN/TXT/?uri=CELEX\%3A32015L0849.

[16] Egmont Group.2004a. "Information paper on Financial Intelligence Units and the Egmont Group, September. Available at http:// www.egmotgroup.org/info_paper_final_oct_2004.pdf.

[17] Asia Pacific Group on Money Laundering official website: www.apgml.org.

[18] Money Laundering Prevention Act, 2012(Act No. V of 2012).

[19] Money Laundering Prevention Rules,2013. 
[20] Anti-Terrorism Act, 2009 (Act No. XVI of 2009).

[21] The daily Star, available at www.thedailystar.net.

[22] www.bdnews24.com.

\section{LIST OF ACRONYMS:}

AML-Anti-Money Laundering

CFT-Combating Financing Terrorism

FIU- Financial Intelligence Unit

BFIU-Bangladesh Financial Intelligence Unit

AMLD-Anti-Money Laundering Department

APG-Asia pacific Group

FATF-Financial Action Task Force

MLPA-Money Laundering Prevention Act

ATA-Anti-Terrorism Act

STR-Suspicious Transaction Report

CTR- Counter Terrorism Report 